\title{
HUBUNGAN MODEL 4A (FOUR $A S$ ) DALAM PEMANFAATAN LAYANAN KESEHATAN PASIEN RAWAT INAP PESERTA BPJS KESEHATAN NON PBI DI RSUD KABUPATEN PANGKEP
}

\section{The Association of 4A Models (Four As) with Health Services Utilization of Patient of BPJS Health Participants in RSUD. Pangkep Regency}

\author{
Chitra Dewi ${ }^{1}$, Anna Nurjannah ${ }^{2}$ \\ Sekolah Tinggi Ilmu Kesehatan Makassar
}

Korespondensi: epidemiologi165@gmail.com

\begin{abstract}
ABSTRAK
Pelayanan kesehatan merupakan hal yang setiap orang dijamin dalam UUD 1945 yang harus diwujudkan dalam upaya dalam meningkatkan derajat kesehatan masyarakat setinggi-tingginya. Terdapat empat faktor yang bisa mempengaruhi pemanfaatan pelayanan kesehatan yakni ketersediaan, keterjangkauan, pembiayaan dan penerimaan pelayanan kesehatan. Tujuan penelitian untuk mengetahui hubungan Model 4A (Four As) dalam pemanfaatan pelayanan kesehatan terhadap pasien rawat inap peserta BPJS kesehatan Non PBI di RSUD Pangkep. Penelitian ini merupakan penelitian analitik dengan desain cross sectional study. Populasi dalam penelitian ini adalah seluruh pasien yang berkunjung selama 1 tahun terakhir sebanyak 6523 kunjungan. Sampel ditarik dengan menggunakan accidential sampling sebesar 98 responden. Hasil penelitian menunjukkan bahwa ada hubungan antara ketersediaan/availability $(\mathrm{p}=0,001)$, aksesibilitas/accessibility $(\mathrm{p}=0,005)$, penerimaan/acceptability $(\mathrm{p}=0,000)$ terhadap pemanfaatan pelayanan kesehatan bagi pasien rawat inap peserta BPJS Kesehatan Non PBI di RSUD Pangkep. Sedangkan tidak ada hubungan antara pembiayaan/affordability $(\mathrm{p}=0,717)$ terhadap pemanfaatan pelayanan kesehatan bagi pasien rawat inap peserta BPJS Kesehatan Non PBI di RSUD Kabupaten Pangkep. Simpulan, ketersediaan (availability), aksesibilitas (accessibility), dan penerimaan (acceptability) memiliki hubungan sedangkan pembiayaan (affordability) tidak memiliki hubungan dalam pemanfaatan pelayanan kesehatan bagi pasien rawat inap peserta BPJS Kesehatan Non PBI di RSUD Kabupaten Pangkep. Saran, untuk meningkatkan kualitas pelayanan kesehatan kepada masyarakat, maka sebaiknya instansi terkait memperhatikan pedoman dalam pemberian mutu pelayanan kepada masyarakat dengan baik, yang sesuai dengan fungsi tenaga kesehatan sebagai abdi masyarakat dan memberikan pelayanan sesuai standar sehingga masyarakat memanfaatkan pelayanan kesehatan secara maksimal.
\end{abstract}

Kata kunci : Model 4A, Four As, Pemanfaatan Layanan Kesehatan, BPJS Kesehatan

\section{ABSTRACT}

Health services is a thing that every person is guaranteed in the 1945 Constitution, which should be realized in an effort to increase the degree of health of the community as high. There are four factors that can influence the utilization of health services namely availability, affordability, financing and acceptance of health services. The aim of research to determine the relationship Model 4A (Four As) in the utilization of services of health of the patient care inpatient participants BPJS health Non PBI in hospitals Pangkep. Research is a research analytic with design cross sectional. The population in the study of this is the whole of patients who visit during the first years of last as many as 6523 visits . Samples were drawn by using accidential sampling of 98 respondents. The results of the study indicate that there is a relationship between availability / availability $(p=0.001)$, accessibility / accessibility ( $p$ $=0.005)$, reception / acceptability $(p=0.000)$ on the utilization of services of health for patients hospitalized inpatient participants BPJS Health Non PBI in hospitals Pangkep. While not there is a relationship between financing / affordability $(p=0.717)$ on the utilization of services of health for patients hospitalized inpatient participants BPJS Health Non PBI in Hospital District Pangkep. 
Conclusion, availability (availability), accessibility (accessibility), and acceptance (acceptability) have a relationship while financing (affordability) do not have a relationship in the utilization of services of health for patients hospitalized inpatient participants BPJS Health Non PBI in Hospital District Pangkep. Advice, to improve the quality of service of health to the public, then it should be institutions related pay attention to the guidelines in the provision of quality service to the public with good, which is in accordance with the function of personnel's health as a man of the people and provide services appropriate standards so that people utilize the services of health as a maximum.

Keyword : $4 A$ Models, Four As, Utilization of health services, BPJS

\section{PENDAHULUAN}

Pelayanan kesehatan dalam UU. NO. 44 tahun 2009 merupakan hal setiap orang yang dijamin dalam UUD 1945 yang harus diwujudkan dengan upaya peningkatan derajat kesehatan masyarakat yang setinggi-tingginya. Rumah sakit sebagai institusi pelayanan kesehatan yang menyelenggarakan pelayanan kesehatan perorangan secara paripurna yang menyediakan pelayanan rawat inap, rawat jalan, dan gawat darurat.

Dalam teori Good (1987) terdapat beberapa hal yang mempengaruhi pemanfaatan layanan kesehatan yakni ketersediaan (availibilty), aksesibilitas (accessibility), pembiayaan/keterjangkauan (affordability), penerimaan (acceptability) yang biasa dikenal dengan Model 4A (Four As). Keempat faktor ini yang kemudian memengaruhi pemanfaatan layanan kesehatan. Karena setiap pelayanan kesehatan baik tingkat puskesmas maupun rumah sakit perlu memiliki fasilitas minimal sesuai standar fasilitas pelayanan kesehatan yang harus tersedia di puskesmas maupun rumah sakit baik itu fasilitas medis dan non medis (Hausmann dan Muela, 2003).
Pelaksanaan pelayanan bagi pasien rawat inap tidak dapat terlepas dari alur proses pelayanan pasien rawat inap. Proses pelayanan pasien unit rawat inap akan mengikuti alur yaitu melalui bagian penerimaan pasien, ruang perawatan dan bagian administrasi dan keuangan (Pahlevi, 2009).

Menurut undang-undang No. 24 tahun 2011 tentang Badan Penyelenggara Jaminan Sosial (BPJS) adalah badan hukum yang dibentuk untuk menyelenggarakan program jaminan sosial. Jaminan Sosial adalah salah satu bentuk perlindungan sosial untuk menjamin seluruh rakyat agar dapat memenuhi kebutuhan dasar hidupnya yang layak. Dalam implementasi SJSN, Pemerintah akan membentuk dua Badan Penyelenggara Jaminan Sosial (BPJS) yaitu BPJS Kesehatan dan BPJS Ketenagakerjaan.

Berdasarkan data BPJS Kesehatan, jumlah peserta sampai desember 2017 ada 169.304.759 juta orang. Banyak fasilitas pelayanan yang berkerjasama dengan BPJS Kesehatan. Di Indonesia, jumlah fasilitas kesehatan yang menerima JKN di lingkup Rumah Sakit sebanyak 1858 (BPJS Info, 2017). Di Indonesia saat ini, dari segi 
ketersediaan pelayanan kesehatan jumlah dan penyebaran tenaga kesehatan masyarakat maupun fasilitas kesehatan masih belum memadai. Hal ini diperburuk oleh distribusi tenaga kesehatan yang tidak merata. Susenas 2017 menunjukkan bahwa masih banyak penduduk ( 93,8 persen) yang harus menunggu pelayanan kesehatan, dalam pembiyaan/ keterjangkauan pelayanan kesehatan, 30\% bersumber dari pemerintah dan $70 \%$ bersumber dari masyarakat termasuk swasta (Susenas, 2017).

Di RSUD. Kabupaten Pangkep, jumlah pengunjung pada tahun 2017 yang menggunakan BPJS Kesehatan sebanyak 43.973 kali kunjungan, 6523 kunjungan diantaranya rawat inap. Gedung rawat inap yang dimiliki RSUD. Kabupaten Pangkep sebanyak 13 gedung, dan tiap gedung rawat inap memiliki 6 hingga 8 kamar, masingmasing gedung terdapat jenis kamar kelas mulai dari kelas 1 sampai ruangan VIP. Jumlah pegawai yang bekerja, terdiri dari 250 PNS dan 520 non PNS.

Sejak awal berlakunya program BPJS yaitu pada tanggal 1 Januari 2014 di RSUD. Kabupaten Pangkep sudah melakukan pelayanan terhadap pasien pengguna BPJS, baik yang termasuk dalam golongan Penerima Bantuan Iuran (PBI) dan bukan Penerima Bantuan Iuran (Non PBI).

Fokus penelitian ini pada pasien peserta BPJS Non PBI. Berdasarkan data mengenai jumlah kunjungan pasien bukan penerima bantuan iuran (Non PBI) JanuariDesember 2017. Rata-rata kunjungan pasien bukan penerima bantuan iuran (Non PBI) selama Januari-Desember 2017 adalah 544 pasien setiap bulannya. Namun jika melihat data yang ada maka angka kunjungan tertinggi berada pada bulan Juli sebanyak 759 pasien dan data kunjungan terendah pada bulan Juni sebanyak 162 pasien.

RSUD. Kabupaten Pangkep sebagai pusat pelayanan kesehatan di tingkat Kabupaten, harus mampu berkembang dan menyesuaikan diri dengan perkembangan ilmu pengetahuan dan tekhnologi, seiring dengan pemenuhan kebutuhan dimana rumah sakit selain sebagai tempat pelayanan paripurna juga diharapkan sebagai pusat rujukan dan sebagai pusat informasi hidup sehat.

Sebagai pusat rujukan dan sebagai pusat informasi hidup sehat, RSUD. Kabupaten Pangkep, masih minim dalam jumlah dokter spesialis dan alat kesehatan (laboratorium seperti pemeriksaan FT4, obgyn sepeti pada pemeriksaan pap smear, instalasi fisioterapi) serta kamar rawat inap.

Terjadi ketidakseimbangan jumlah pasien rawat inap dengan jumlah kamar inap, sehingga sering terjadi penumpukan pasien di UGD diakibatkan banyak pasien yang menunggu pasien rawat inap hingga check out untuk mendapatkan kamar rawat inap. Dalam hal dokter spesialis, RSUD. Kabupaten Pangkep memiliki 26 dokter yang berwenang pada pemeriksaan rawat jalan, akan tetapi 
terjadi ketidakseimbangan jumlah dokter disetiap bagian, sehingga terjadi keterlambatan pelayanan kesehatan terutama di pasien rawat jalan yang hanya memiliki 1 dokter spesialis. Alat kesehatan yang dimiliki di RSUD. Kabupaten Pangkep pun masih minim dalam beberapa bagian instalasi, terumata instalasi laboratorium, sehingga pemeriksaan yang tidak dimiliki dirujuk ke Rumah Sakit yang berada di Kota Makassar.

Dalam hal penerimaan pelayanan kesehatan terhadap petugas pelayanan yang diukur dari ketepatan waktu petugas, ketampilan petugas, kemarahan petugas dan kepercayaan pasien. Ditemukan dari sampel yang diteliti sebanyak 55 responden merasa mendapatkan penerimaan yang kurang baik. Sehingga RSUD. Kabupaten Pangkep sekarang ini mulai melakukan pembenahan salah satunya dengan membuat slogan "melayani dengan keikhlasan".

Dalam penggunaan 4A (Four As) di RSUD. Kabupaten Pangkep peneliti merasa bahwa 4A (Four As) tersebut jika diterapkan di Rumah Sakit tersebut akan bermanfaat terhadap pasien khususnya pasien rawat inap peserta BPJS Kesehatan, apalagi saat ini RSUD. Kabupaten Pangkep dalam penilaian akreditasi. Hasil dari kunjungan tahap I tim KARS, Rumah Sakit tersebut memerlukan pembenahan dalam beberapa hal. Oleh karena itu, peneliti berinisiatif untuk mengukur pemanfaatan layanan kesehatan menggunakan model tersebut.
Sehubungan dengan kondisi tersebut maka peneliti merasa perlu untuk mengetahui hubungan 4A (Four As) dalam pemanfaatan layanan kesehatan pasien rawat inap terhadap pasien peserta BPJS Kesehatan di RSUD. Kabupaten Pangkep. Karena keterbatasan peneliti, sehingga penelitian ini hanya difokuskan pada pasien rawat inap peserta BPJS Non PBI.

\section{BAHAN DAN METODE}

Penelitian ini merupakan jenis penelitian deskriptif dengan pendekatan cross sectional. Penelitian dilakukan pada bulan 27 Agustus 2018 sampai dengan tanggal 10 September 2018. Lokasi penelitian di RSUD. Kabupaten Pangkep yang berada di Kota Pangkajene. Populasi dalam penelitian ini adalah seluruh pasien rawat inap pengguna BPJS Kesehatan Non PBI di RSUD. Kabupaten Pangkep dari bulan Januari sampai bulan Desember tahun 2017 yaitu berjumlah 6.523 pasien.

Jumlah total sampel adalah 98 responden, Teknik pengambilan sampel dalam penelitian ini adalah non probability sampling dengan menggunakan accidental sampling

Data diambil dengan menyebarkan kuesioner pada sampel dan melakukan observasi atau pengamatan langsung. Selain itu, juga diperoleh dari instansi setempat dalam hal ini di RSUD. Kabupaten Pangkep. 


\section{HASIL}

\section{a. Karakteristik Responden}

Tabel 1

Karakteristik Responden Pasien Rawat Inap Peserta BPJS Kesehatan Non PBI di RSUD. Kabupaten Pangkep Tahun 2018

\begin{tabular}{lcc}
\hline \multicolumn{1}{c}{ Variabel } & n & \% \\
\hline Umur (Tahun) & 25 & 25.5 \\
$20-28$ & 17 & 17.3 \\
$29-37$ & 24 & 24.5 \\
$38-46$ & 20 & 20.4 \\
$47-55$ & 7 & 7.1 \\
$56-64$ & 5 & 5.1 \\
$65-73$ & & \\
\hline Pekerjaan & 29 & 29.6 \\
Tidak bekerja & 26 & 26.5 \\
Pedagang/Wiraswasta & 4 & 4.1 \\
Buruh & 2 & 2.0 \\
Petani & 25 & 25.5 \\
PNS & 12 & 12.2 \\
Pegawai Swasta & & \\
\hline Pendidikan & 6 & 6.1 \\
Tidak Pernah Sekolah & 2 & 2.0 \\
Tidak Tamat SD & 20 & 20.4 \\
Tamat SD & 7 & 7.1 \\
Tidak Tamat SMP & 17 & 17.3 \\
Tamat SMP & 7 & 7.1 \\
Tidak Tamat SMA & 21 & 21.4 \\
Tamat SMA & 18 & 18.4 \\
Perguruan Tinggi & $\mathbf{9 8}$ & $\mathbf{1 0 0}$ \\
\hline Jumlah & & \\
\hline
\end{tabular}

Tabel 1 menunjukkan distribusi karakteristk responden berdasarkan umur yang tertinggi yaitu umur 20-28 sebanyak 25 orang $(25,5 \%)$, sedangkan yang terendah yaitu umur 65-73 sebanyak 5 orang (5,1\%). Berdasarkan pekerjaan tertinggi yaitu tidak bekerja sebanyak 29 orang $(29,59 \%)$, sedangkan yang terendah yaitu petani sebanyak 2 orang $(2,0 \%)$. Sedangkan dari segi pendidikan yang tertinggi yaitu tamat SMA sebanyak 21 orang $(21,4 \%)$, sedangkan yang terendah yaitu tidak tamat SD sebanyak 2 orang $(2,0 \%)$.

\section{b. Ketersediaan (Availability)}

Ketersediaan (availability) adalah kelengkapan fasilitas pelayanan kesehatan pada Rumah Sakit yang berupa ketersediaan obat dan segala jenis peralatan, perlengkapan kerja dan fasilitas lainnya yang berfungsi sebagai alat utama/pembantu dalam pelaksanaan pekerjaan di Rumah Sakit.

Tabel 2 menunjukkan bahwa dari 98 orang responden, bahwa sekitar 72 orang $(73,5 \%)$ yang memberikan penilaian ketersediaan fasilitas pelayanan kesehatan (availability) dan sekitar 26 orang (26,5\%) yang menyatakan tidak tersedianya fasilitas pelayanan kesehatan pada pasien rawat inap peserta BPJS Kesehatan non PBI di RSUD. Kabupaten Pangkep.

\section{Tabel 2}

Distribusi Responden Berdasarkan Penilaian Availability Pada Pasien Rawat Inap Peserta BPJS Kesehatan Non PBI Di RSUD. Kabupaten Pangkep Tahun 2018

\begin{tabular}{ccc}
\hline Availability & $\mathbf{n}$ & $\mathbf{\%}$ \\
\hline Tersedia & 72 & 73,5 \\
Tidak tersedia & 26 & 26,5 \\
\hline Jumlah & $\mathbf{9 8}$ & $\mathbf{1 0 0}$ \\
\hline
\end{tabular}

\section{c. Aksesibilitas (Accessibility)}

Aksesibilitas (accessibility) adalah keterjangkauan tempat pelayanan 
kesehatan yang dapat diukur dengan jarak dan waktu yang ditempuh oleh pasien menuju ke tempat pelayanan kesehatan tersebut.

\section{Tabel 3}

Distribusi Responden Berdasarkan Penilaian Accessibility Pada Pasien Rawat Inap Peserta BPJS Kesehatan Non PBI Di RSUD.

Kabupaten Pangkep Tahun 2018

\begin{tabular}{ccc}
\hline Accessibility & n & \% \\
\hline Mudah & 91 & 92.9 \\
Tidak Mudah & 7 & 7.1 \\
\hline Jumlah & $\mathbf{9 8}$ & $\mathbf{1 0 0}$ \\
\hline
\end{tabular}

Tabel 3 menunjukkan bahwa dari 98 responden yang menyatakan bahwa sekitar 91 orang $(92,9 \%)$ yang memberikan penilaian aksesibilitas pelayanan kesehatan (accessibility) yang mudah dan sekitar 7 orang $(7,1 \%)$ yang memberikan penilaian aksesibilitas pelayanan kesehatan (accessibility) yang tidak mudah pada pasien rawat inap peserta BPJS Kesehatan non PBI di RSUD. Kabupaten Pangkep.

\section{d. Pembiayaan (Affordability)}

Pembiayaan

(affordability)

berhubungan dengan aspek harga atau biaya dari jasa pelayanan yang telah diterima, berupa kemampuan untuk membayar, baik langsung, persyaratan deposit dari pendapatan dan asuransi kesehatan.

Tabel 4 menunjukkan bahwa dari 98 responden yang menyatakan bahwa sekitar 90 orang $(91,8 \%)$ yang memberikan penilaian pembiayaan pelayanan kesehatan (affordability) yang sesuai dan sekitar 8 orang $(8,2 \%)$ yang memberikan penilaian pembiayaan (affordability) yang tidak sesuai pada pasien rawat inap peserta BPJS Kesehatan non PBI di RSUD. Kabupaten Pangkep.

\section{Tabel 4}

Distribusi Responden Berdasarkan Penilaian Affordability Pada Pasien Rawat Inap Peserta BPJS Kesehatan Non PBI Di RSUD. Kabupaten Pangkep Tahun 2018

\begin{tabular}{ccc}
\hline Affordability & $\mathbf{n}$ & $\mathbf{\%}$ \\
\hline Sesuai & 90 & 91.8 \\
Tidak Sesuai & 8 & 8.2 \\
\hline Jumlah & $\mathbf{9 8}$ & $\mathbf{1 0 0}$ \\
\hline
\end{tabular}

\section{e. Penerimaan (Acceptability)}

Penerimaan (acceptability) adalah perilaku dan sikap petugas serta keterampilan dan tanggung jawab petugas saat memberikan pelayanan kesehatan di rumah sakit.

\section{Tabel 5}

Distribusi Responden Berdasarkan Penilaian Acceptability Pada Pasien Rawat Inap Peserta BPJS Kesehatan Non PBI Di RSUD. Kabupaten Pangkep Tahun 2018

\begin{tabular}{ccc}
\hline Acceptability & n & \% \\
\hline Baik & 43 & 43.9 \\
Kurang Baik & 55 & 56.1 \\
\hline Jumlah & $\mathbf{9 8}$ & $\mathbf{1 0 0}$ \\
\hline
\end{tabular}

Tabel 5 menunjukkan bahwa dari 98 responden yang menyatakan bahwa sekitar 55 orang $(56,1 \%)$ yang memberikan penilaian penerimaan pelayanan kesehatan 
(acceptability) yang kurang baik dan sekitar 43 orang $(43,9 \%)$ yang memberikan penilaian penerimaan pelayanan kesehatan (acceptability) yang baik pada pasien rawat inap peserta BPJS Kesehatan non PBI di RSUD. Kabupaten Pangkep.

\section{f. Pemanfaatan Pelayanan Kesehatan}

Pemanfaatan pelayanan kesehatan adalah suatu tindakan yang dilakukan untuk mendatangkan perubahan bagi kesehatan yang semula sakit menjadi sehat kembali. Dalam hal ini akan membahas pemanfaatan pelayanan kesehatan bagi pasien BPJS Kesehatan Non PBI.

\section{Tabel 6}

Distribusi Responden Berdasarkan Pemanfaatan Pelayanan Kesehatan Pada Pasien Rawat Inap Peserta BPJS Kesehatan Non PBI di RSUD. Kabupaten Pangkep Tahun 2018

\begin{tabular}{ccc}
\hline $\begin{array}{c}\text { Pemanfaatan Pelayanan } \\
\text { Kesehatan }\end{array}$ & n & \% \\
\hline Memanfaatkan & 51 & 52.0 \\
Tidak Memanfaatkan & 47 & 48,0 \\
\hline Jumlah & $\mathbf{9 8}$ & $\mathbf{1 0 0}$ \\
\hline
\end{tabular}

Berdasarkan tabel 6 dapat diketahui bahwa dari 98 responden, yang memanfaatkan pelayanan kesehatan dengan baik yaitu sebanyak 51 orang $(52.0 \%)$, sedangkan yang tidak memanfaatkan pelayanan kesehatan di RSUD. Kabupaten Pangkep yaitu sebanyak 47 orang $(48,0 \%)$.

Tabel 7

Hubungan Antara Availability dengan Pemanfaatan Pelayanan Kesehatan Bagi Pasien BPJS Kesehatan Non PBI Di RSUD. Kabupaten Pangkep Tahun 2018

\begin{tabular}{|c|c|c|c|c|c|c|c|}
\hline \multirow{3}{*}{ Availability } & \multicolumn{4}{|c|}{ Pemanfaatan Pelayanan Kesehatan } & \multirow{2}{*}{\multicolumn{2}{|c|}{ Total }} & \multirow[b]{2}{*}{$\mathbf{p}$} \\
\hline & \multicolumn{2}{|c|}{ Memanfaatkan } & \multicolumn{2}{|c|}{$\begin{array}{c}\text { Tidak } \\
\text { Memanfaatkan }\end{array}$} & & & \\
\hline & $\mathbf{n}$ & $\%$ & $\mathbf{n}$ & $\%$ & $\mathrm{n}$ & $\%$ & \multirow{4}{*}{0,001} \\
\hline Tersedia & 45 & 62,5 & 27 & 37,5 & 72 & 100 & \\
\hline Tidak Tersedia & 6 & 23,1 & 20 & 76,9 & 26 & 100 & \\
\hline Total & 51 & 52,0 & 47 & 48,0 & 98 & 100 & \\
\hline
\end{tabular}

g. Hubungan antara Availability dengan Pemanfaatan Pelayanan Kesehatan

Hubungan antara availability dengan pemanfaatan pelayanan kesehatan bagi pasien BPJS Kesehatan di RSUD. Kabupaten Pangkep (tabel 7) menunjukkan bahwa dari 98 orang responden, sebanyak 72 orang yang memberikan penilaian ketersediaan fasilitas pelayanan kesehatan (availability), yang terdiri dari 45 orang $(62,5 \%)$ yang memanfaatkan pelayanan kesehatan dan 27 orang $(37,5 \%)$ yang tidak memanfaatkan pelayanan kesehatan. Sedangkan dari 26 orang 
yang memberikan penilaian tidak adanya ketersediaan fasilitas pelayanan kesehatan (availability), yang terdiri dari 20 orang (76,9\%) yang tidak memanfaatkan pelayanan kesehatan dan 6 orang $(23,1 \%)$ yang memanfaatkan pelayanan kesehatan.

Hasil uji chi square dengan $\mathrm{p}=0,001$ dimana $P<0,05$ yang berarti menunjukkan bahwa ada hubungan ketersediaan fasilitas pelayanan kesehatan (availability) dengan pemanfaatan pelayanan kesehatan bagi pasien rawat inap peserta BPJS kesehatan Non PBI di RSUD. Pangkep tahun 2018.

h. Hubungan antara Accessibility dengan Pemanfaatan Pelayanan Kesehatan

Hubungan antara accessibility dengan pemanfaatan pelayanan kesehatan bagi pasien BPJS Kesehatan di RSUD Kabupaten Pangkep (tabel 8) menunjukkan bahwa dari 98 orang responden, sekitar 91 orang yang memberikan penilaian aksesibilitas pelayanan kesehatan (accessibility) yang mudah, terdiri dari 51 orang $(56,0 \%)$ yang memanfaatkan pelayanan kesehatan dan 40 orang $(44,0 \%)$ yang tidak memanfaatkan pelayanan kesehatan. Sedangkan dari 7 orang responden $(100 \%)$ yang memberikan penilaian aksesibilitas pelayanan kesehatan (accessibility) yang tidak mudah diakses dan tidak memanfaatkan pelayanan kesehatan.

Hasil uji chi square dengan nilai $\mathrm{p}=0,005 \quad$ dimana $\quad P<0,05$ yang berarti menunjukkan bahwa ada hubungan hubungan kemudahan dalam mengakses pelayanan kesehatan (accessibility) dengan pemanfaatan pelayanan kesehatan bagi pasien rawat inap peserta BPJS kesehatan Non PBI di RSUD. Kab. Pangkep tahun 2018.

Tabel 8

Hubungan Antara Accessibility dengan Pemanfaatan Pelayanan Kesehatan Bagi Pasien BPJS Kesehatan Non PBI di RSUD. Kabupaten Pangkep Tahun 2018

\begin{tabular}{cccccccc}
\hline & \multicolumn{3}{c}{ Pemanfaatan Pelayanan Kesehatan } & \multirow{2}{*}{ Total } & \multirow{2}{*}{ Tidak } \\
\cline { 2 - 5 } Accessibility & \multicolumn{2}{c}{ Memanfaatkan } & \multicolumn{2}{c}{ Memanfaatkan } & & \\
\cline { 2 - 6 } & $\mathbf{n}$ & $\mathbf{\%}$ & $\mathbf{n}$ & $\mathbf{\%}$ & $\mathrm{n}$ & $\%$ & \\
\hline Mudah & 51 & 56,0 & 40 & 44,0 & 91 & 100 & \\
Tidak mudah & 0 & 0 & 7 & 100 & 7 & 100 & 0,005 \\
\hline Total & $\mathbf{5 1}$ & $\mathbf{5 2 , 0}$ & $\mathbf{4 7}$ & $\mathbf{4 8 , 0}$ & $\mathbf{9 8}$ & $\mathbf{1 0 0}$ & \\
\hline
\end{tabular}

i. Hubungan antara Affordability dengan Pemanfaatan Pelayanan Kesehatan

Hubungan antara affordability dengan pemanfaatan pelayanan kesehatan bagi pasien BPJS Kesehatan di RSUD. Kabupaten Pangkep (tabel 9) menunjukkan bahwa dari 98 responden, sebanyak 90 orang yang memberikan penilaian pembiayaan pelayanan kesehatan (affordability) yang sesuai, yang terdiri dari 46 orang $(51,1 \%)$ yang memanfaatkan pelayanan kesehatan dan 44 orang $(48,9 \%)$ yang tidak memanfaatkan pelayanan kesehatan. Sedangkan dari 8 orang yang memberikan penilaian pembiayaan 
pelayanan kesehatan (affordability) yang tidak sesuai, terdiri dari 5 orang $(62,5 \%)$ yang memanfaatkan pelayanan kesehatan dan 3 orang $(37,5 \%)$ yang tidak memanfaatkan pelayanan kesehatan.

Tabel 9

Hubungan Antara Affordability dengan Pemanfaatan Pelayanan Kesehatan Bagi pasien BPJS Kesehatan di RSUD. Kabupaten Pangkep Tahun 2018

\begin{tabular}{|c|c|c|c|c|c|c|c|}
\hline \multirow{3}{*}{ Affordability } & \multicolumn{4}{|c|}{ Pemanfaatan Pelayanan Kesehatan } & \multirow{2}{*}{\multicolumn{2}{|c|}{ Total }} & \multirow{2}{*}{$\mathbf{p}$} \\
\hline & \multicolumn{2}{|c|}{ Memanfaatkan } & \multicolumn{2}{|c|}{$\begin{array}{c}\text { Tidak } \\
\text { Memanfaatkan }\end{array}$} & & & \\
\hline & n & $\%$ & n & $\%$ & $\mathrm{n}$ & $\%$ & \multirow{4}{*}{$\mathrm{p}=0,717$} \\
\hline Sesuai & 46 & 51,1 & 44 & 48,9 & 90 & 100 & \\
\hline Tidak Sesuai & 5 & 62,5 & 3 & 37,5 & 8 & 100 & \\
\hline Total & 51 & 52,0 & 47 & 48,0 & 98 & 100 & \\
\hline
\end{tabular}

Hasil uji chi square dengan nilai $\mathrm{p}=0,717$ dimana $P>0,05$ yang berarti menunjukkan bahwa tidak ada hubungan antara dengan pemanfaatan pelayanan kesehatan bagi

keterjangkauan pembiayaan (affordability) pasien rawat inap peserta BPJS kesehatan Non PBI di RSUD. Kab. Pangkep tahun 2018.

Tabel 10

Hubungan Antara Acceptability dengan Pemanfaatan Pelayanan Kesehatan Bagi Pasien BPJS Kesehatan Di RSUD. Kabupaten Pangkep Tahun 2018

\begin{tabular}{|c|c|c|c|c|c|c|c|}
\hline \multirow{3}{*}{ Acceptability } & \multicolumn{4}{|c|}{ Pemanfaatan Pelayanan Kesehatan } & \multirow{2}{*}{\multicolumn{2}{|c|}{ Total }} & \multirow[b]{2}{*}{$\mathbf{p}$} \\
\hline & \multicolumn{2}{|c|}{ Memanfaatkan } & \multicolumn{2}{|c|}{$\begin{array}{c}\text { Tidak } \\
\text { Memanfaatkan }\end{array}$} & & & \\
\hline & $\mathbf{n}$ & $\%$ & $\mathbf{n}$ & $\%$ & $\mathrm{n}$ & $\%$ & \multirow{4}{*}{$\mathrm{p}=0.000$} \\
\hline Baik & 35 & 81,4 & 8 & 18,6 & 43 & 100 & \\
\hline Kurang baik & 16 & 29,1 & 39 & 70,9 & 55 & 100 & \\
\hline Total & 51 & 52,0 & 47 & 48,0 & 98 & 100 & \\
\hline
\end{tabular}

\section{j. Hubungan antara Acceptability dengan Pemanfaatan Pelayanan Kesehatan}

Hubungan antara acceptability dengan pemanfaatan pelayanan kesehatan bagi pasien BPJS Kesehatan di RSUD. Kabupaten Pangkep (Tabel 10) menunjukkan bahwa dari 98 orang responden, sebanyak 55 orang yang memberikan penilaian penerimaan pelayanan kesehatan (acceptability) yang kurang baik, yang terdiri dari 39 orang $(70,9 \%)$ yang tidak memanfaatkan pelayanan kesehatan dan 16 orang $(29,1 \%)$ yang memanfaatkan pelayanan kesehatan. Sedangkan sekitar 43 orang yang memberikan penilaian penerimaan pelayanan kesehatan (acceptability) yang baik, terdiri dari 35 orang $(81,4 \%)$ yang memanfaatkan pelayanan kesehatan dan 8 orang $(18,6 \%)$ yang 
tidak memanfaatkan pelayanan kesehatan.

Hasil uji chi square dengan nilai $\mathrm{p}=0,000$ dimana $P<0,05$ yang berarti menunjukkan bahwa ada hubungan penerimaan (accessibility) dengan pemanfaatan pelayanan kesehatan bagi pasien rawat inap peserta BPJS kesehatan Non PBI.

\section{PEMBAHASAN}

\section{a. Availability}

Ketersediaan (availability) merupakan indikator penilaian yang ditinjau dari segi kelengkapan fasilitas pelayanan kesehatan pada rumah sakit yang berupa ketersediaan obat dan segala jenis peralatan, perlengkapan kerja dan fasilitas lainnya yang berfungsi sebagai alat utama/pembantu dalam pelaksanaan pekerjaan di rumah sakit. Ketersediaan fasilitas kesehatan menjadi salah satu faktor yang mendorong masyarakat dalam memanfaatkan pelayanan Kesehatan.

Hasil penelitian ini menunjukkan bahwa ada hubungan ketersediaan fasilitas (availability) dengan pemanfaatan pelayanan kesehatan bagi pasien rawat inap peserta BPJS kesehatan Non PBI di RSUD. Kabupaten Pangkep. dengan hasil uji statistik $(\mathrm{p}=0,001)$. Pasien yang memanfaatkan pelayanan kesehatan di RSUD. Kabupaten Pangkep dalam hal ini pasien BPJS Kesehatan mengatakan bahwa ketersediaan fasilitas kesehatan sangat mempengaruhi pemanfaatan pelayanan kesehatan di RSUD. Kabupaten Pangkep.

Semakin lengkap fasilitas kesehatan yang diterima semakin tinggi pula minat kunjungan pasien untuk memanfaatkan pelayanan kesehatan di RSUD. Kabupaten Pangkep, ini disebabkan karena pasien merasa bahwa dengan tersedianya fasilitas yang lengkap serta memadai akan mendukung pemenuhan kebutuhan pasien mengenai pelayanan kesehatan. Apa yang mereka butuhkan dapat terpenuhi dalam pelayanan yang diberikan. Hal ini tentunya didukung penuh oleh tingkat Pendidikan dan pengetahuan masyarakat. Karena hal ini yang mampu menjadi pendorong pergerakan masyarakat untuk memanfaatkan pelayanan kesehatan yang ada.

Hasil penelitian ini sejalan dengan hasil penelitian yang dilakukan oleh Alfiati (2013) menyatakan bahwa terdapat hubungan yang bermakna antara fasilitas kesehatan dengan pemanfaatan pelayanan poli obsgyn di RSUD Banjarnegara. Sehingga hal ini semakin menguatkan kesimpulan peneliti.

\section{b. Accessibility}

Aksesibilitas (accessibility) adalah keterjangkauan tempat pelayanan kesehatan yang dapat diukur dengan jarak dan waktu temput serta transportasi yang digunakan oleh pasien menuju ketempat pelayanan kesehatan tersebut.

Hasil penelitian ini menunjukkan bahwa ada hubungan antara accessibility dengan pemanfaatan pelayanan kesehatan bagi pasien rawat inap peserta BPJS kesehatan Non PBI di RSUD. Kabupaten Pangkep dengan hasil uji statistik $(\mathrm{p}=0,005)$. 
Semakin mudah sebuah fasilitas pelayanan kesehatan untuk dijangkau maka akan berbanding lurus dengan pemanfaatan pelayanan kesehatan. Artinya, jika masyarakat mampu menjangkau rumah sakit dengan jarak yang dekat dan dalam waktu yang cepat tentunya akan meningkatkan pemanfaatan pelayanan kesehatan yang tersedia. Jika melihat kondisi geografis yang dimiliki oleh Kab. Pangkep yang terdiri dari daratan, pegunungan, dan juga lautan, maka tentu saja masyarakat yang berada dalam area terdekat dengan rumah sakit akan lebih mudah menjangkau pelayanan kesehatan di RSUD. Kabupaten Pangkep.

Penelitian ini sejalan dengan penelitian Nurjanna (2015) juga menyatakan bahwa ada

\section{c. Affordability}

Pembiayaan

(affordability)

berhubungan dengan aspek harga atau biaya dari jasa pelayanan yang telah diterima.

Hasil penelitian ini menunjukkan bahwa tidak ada hubungan antara Affordability dengan pemanfaatan pelayanan kesehatan bagi pasien rawat inap peserta BPJS kesehatan Non PBI dengan hasil uji statistik $(\mathrm{p}=0,717)$ dimana $\mathrm{p}>0,05$ Pasien yang memanfaatkan pelayanan kesehatan di RSUD. Kabupaten Pangkep dalam hal ini pasien BPJS Kesehatan mengatakan bahwa harga atau tarif dalam pembiayaan pelayanan kesehatan tidak mempengaruhi pemanfaatan pelayanan kesehatan di RSUD. Kabupaten Pangkep. pengaruh variabel jarak terhadap pemanfaatan pelayanan kesehatan pada Ruang Rawat Inap RSU. Tenriawaru Kab. Bone dengan hasil uji statistik diperoleh nilai $\mathrm{p}=0,004$ atau $\mathrm{p}<0,05$. Hasil tersebut membuktikan bahwa variabel jarak berpengaruh terhadap pemanfaatan pelayanan kesehatan. Hal ini disebabkan karena masyarakat cenderung akan mempertimbangkan jarak antara lokasi rumah dan pelayanan kesehatan yang mereka miliki.

Hal ini juga sejalan dengan hasil penelitian yang dilakukan oleh Purba (2014) yang menujukkan bahwa ada hubungan yang signifikan antara aksesibilitas responden dengan pemanfaatan jamkesmas dengan hasil uji satistik $\mathrm{p}=0,02$.

Penelitian ini sejalan dengan hasil penelitian Rahangiar (2015) yang menyatakan bahwa tidak ada hubungan antara affordability dengan pemanfaatan jaminan persalinan di Puskesmas Ohoijang. Biaya cenderung tidak menghambat pemanfaatan pelayanan kesehatan oleh masyarakat. Hal ini didasari karena peserta BPJS Kesehatan Non PBI akan tetap membayar iuran secara teratur setiap bulannya.

Dalam Sirmayanti (2016) menyatakan bahwa hasil uji statistik dengan menggunakan uji Chi Square diperoleh nilai $\mathrm{p}=0,10$ atau nilai $\mathrm{p}>0,05$. Dengan demikian, maka $\mathrm{Ha}$ ditolak berarti tidak ada hubungan antara affordability dengan pemanfaatan pelayanan kesehatan bagi masyarakat di Puskesmas Antara. 


\section{d. Acceptability}

Penerimaan (acceptability) adalah perilaku dan sikap petugas serta keterampilan petugas saat memberikan pelayana kesehatan. Sikap baik dari petugas dan pemberi pelayanan kesehatan adalah salah satu faktor yang dapat mempengaruhi pemanfaatan pelayanan kesehatan.

Hasil penelitian ini menunjukkan bahwa ada hubungan antara Acceptability dengan pemanfaatan pelayanan kesehatan bagi pasien BPJS Kesehatan di RSUD. Kabupaten Pangkep. Dengan hasil uji statistik dengan menggunakan uji Chi Square diperoleh nilai $\mathrm{p}$ $=0,000$ atau nilai $\mathrm{p}<0,05$.

Penerimaan atau pemberian perilaku dalam pelayanan oleh tenaga kesehatan tentunya memiliki pengaruh yang sangat besar dalam keinginan masyarakat untuk memanfaatkan pelayanan kesehatan yang ada. Sikap, tutur kata, serta segala kemudahan yang diberikan dari seluruh unsur pendukung pelayanan yang ada dalam sebuah rumah sakit mulai dari pelayanan saat costumer service, dokter, bidan, perawat, hingga cleaning service menjadi hal yang akan mendorong masyarakat untuk merasa lebih dihargai dan menerima pelayanan tersebut dengan baik. Penelitian ini sejalan dengan penelitian Rahmayanti (2015) Menyatakan, bahwa terdapat hubungan antara Acceptability dengan pemanfaatan pelayanan antenatal care.
Dalam penelitian Nurjannah (2010) yang menyatakan bahwa ada pengaruh respon dokter/perawat terhadap pemanfaatan pelayanan kesehatan di Ruang Rawat Inap RSU Tenriawaru Kab. Bone dengan hasil uji statistik diperoleh nilai $\mathrm{p}=0,011$ atau $\mathrm{p}<0,05$. Dan dalam penelitian Magan menyatakan bahwa ada hubungan antara sikap petugas dengan pemanfaatan pelayanan kesehatan di Puskesmas Makale Kec. Makale dengan hasil uji chi square diperoleh nilai $\mathrm{p}=0,020$.

Dengan demikian, untuk meningkatkan pemanfaatan pelayanan kesehatan khususnya bagi pasien BPJS Kesehatan di RSUD. Kabupaten Pangkep diperlukan dukungan pelayanan petugas di Rumah Sakit yang berorientasi pada mutu dan kepuasan pelanggan sehingga masyarakat tidak perlu merasa malu, takut, dan enggan untuk berobat ke rumah sakit tersebut.

\section{SIMPULAN}

1. Ada hubungan antara ketersediaan (availability) dengan pemanfaatan pelayanan kesehatan pasien rawat inap peserta BPJS Kesehatan non PBI $(p=0,001)$.

2. Ada hubungan antara aksesibilitas (accessibility) dengan pemanfaatan pelayanan kesehatan pasien rawat inap peserta BPJS Kesehatan non PBI $(\mathrm{p}=0,005)$.

3. Tidak ada hubungan antara pembiayaan (affordability) dengan pemanfaatan 
pelayanan kesehatan pasien rawat inap peserta BPJS Kesehatan non PBI $(\mathrm{p}=0,717)$.

4. Ada hubungan antara penerimaan (acceptability) dengan pemanfaatan pelayanan kesehatan pasien rawat inap peserta BPJS Kesehatan non PBI $(p=0,000)$.

\section{SARAN}

1. Pemeriksaan alat-alat kesehatan secara berkala sebaiknya dilakukan, sehingga hal tersebut mendukung ketersediaan fasilitas yang memadai dalam rangka memaksimalkan potensi yang ada, sehingga tujuan untuk memberikan pelayanan kepada masyarakat yang sesuai standar bisa terwujud.

2. Bagi peneliti selanjutnya yang ingin lebih dalam menggali informasi terkait pemanfaatan pelayanan kesehatan, disarankan untuk mengembangkan penelitian ini dengan melihat faktor lain yang belum terdapat dalam penelitian ini dengan memperhatikan tehnik sampling yang tepat, sehingga hasil penelitian bisa lebih representative untuk mewakili popolasi.

\section{DAFTAR PUSTAKA}

Aditama. 2004. Manajemen Administrasi Rumah Sakit. UI-Press. Jakarta.

Anggraini, D. 2008. Perbandingan Kepuasan Pasien Gakin dan Pasien Umum di Unit Rawat Inap RSUD Budhi Asih Tahun
2008. Skripsi. Program Sarjana Fakultas Kesehatan Masyarakat Universitas Indonesia, Depok.

Azwar, A. 2010. Pengantar Administrasi Kesehatan. Binarupa Aksara. Jakarta.

DPR RI UU RI No 44 Tahun 2009, tentang Rumah Sakit, Jakarta, 2009

Hausmann-Muela, S. 2003. Health-Seeking Behaviour and The Health System Response. DCPP Working Paper No 14. Geneva. WHO.

Kementerian Kesehatan RI. 2013. Buku Pegangan Sosialisasi Jaminan Kesehatan Nasional (JKN) dalam Sistem Jaminan Sosial Nasional. Kementrian Kesehatan Republik Indonesia. Jakarta.

Kementerian Kesehatan RI. 2013. Peraturan Kesehatan RI No 12 Tahun 2013 tentang Standar Jaminan Kesehatan.

Laksono. 2006. Aspek Strategi Manajemen Rumah Sakit Antara Misi Sosial dan Tekanan Pasar. Andi. Yogyakarta.

Marni. 2011. Asuhan Kebidanan Pada Masa Antenatal. Pustaka Belajar. Yogyakarta.

Maulana,A 2013, Sistem Pelayanan Kesehatan, http://aamaulana96.blogspot.com/2013/0 3/sistem-pelayanan-kesehatan.html? $\mathrm{m}=1$ diakses tanggal 28 Agustus 2018 pukul 20.55 WITA.

Notoatmodjo, S. 2012. Metodologi penelitian Kesehatan. Cetakan kedua. Rineka Cipta. Jakarta.

Pahlevi, 2009. Analisis Pelayanan Pasien Rawat Inap di Unit Adinistrasi RSUD Budhi Asih Jakarta Timur Tahun 2009. Skripsi. Program Sarjana Fakultas Kesehatan Masyarakat UI, Depok.

Pangkep, R. 2017. Profil RSUD. Kabupaten Pangkep.

Permenkes No 340/MENKES/PER/III/2010 Tentang Klasifikasi Rumah Sakit. 2010.

Rumengan, D.S., 2013. Faktor-faktor yang berhubungan dengan pemanfaatn pelayanan kesehatan pada peserta BPJS 
http://journal.unpacti.ac.id/index.php/JPP

Kesehatan di Puskesmas Paniki bawah kecamatan mapanget Kota Manado. http//www.jurnalmikmu.com. $6 \quad$ Juni (10.15).

Sarbaguna. dan Boy S. 2004. Sumber Daya Manusia Rumah Sakit. Konsorsium RS Islam Jawa Tengah. Yogyakarta.

Satrianegara, 2009. Organisasi dan Manajemen Pelayanan Kesehatan serta Kebidanan. Salemba Medika. Jakarta.

Siregar, C.J.P.2004. Farmasi Rumah Sakit. Buku Kedokteran ECG. Jakarta.

Sugiono. 2013. Metode Penelitian Kuantitatif Kualitatif dan R \& D. Alfabeta. Bandung Undang-Udang Republik Indonesia Nomor 24

Tahun 2011. Badan Penyelenggara Jaminan Sosial. 25 November 2011. Lembaran Negara Republik Indonesia Tahun 2011 Nomor 116. Jakarta. 